\title{
Assessment of the assortment potential of the growing stock - a photogrammetry based approach for an automatized grading of sample trees
}

\author{
Christine FÜRST ${ }^{\mathrm{a} *}$, Gérard NEPVEU ${ }^{\mathrm{b}}$ \\ ${ }^{\text {a }}$ Dresden University of Technology, Institute for Soil Science and Site Ecology, Pienner Road 19, 01737 Tharandt, Germany \\ ${ }^{\mathrm{b}}$ LERFOB, Laboratoire d'Étude des Ressources Forêt-Bois, UMR INRA-ENGREF, Centre INRA de Nancy, 54280 Champenoux, France
}

(Received 15 August 2005; accepted 3 April 2006)

\begin{abstract}
The presented paper introduces a photogrammetry based value inventory method including an electronic grading routine. The grading is realized by an automatic identification of stem surface features in eCognition. ECognition is an image analysis system using a polygon-oriented segmentation and a fuzzy logic based classification. The feature-related parameterisation within eCognition is oriented on key assortment criteria originating from timber selling contracts in two test regions in Saxony (Germany). A total of eight Norway spruces (Picea abies, Karst.) and eight Scots pines (Pinus sylvestris L.) was selected as sample material for the development of the classification process in eCognition. For two further sample trees one Norway spruce and one Scots pine - the differences between a "normal", i.e. visual sorting and a picture-interpretation supported and consequently more detailed sorting are presented. In the context of forest inventory, the presented approach can support the acquirement of detailed sample-tree-based information on the assortment distribution at the level of management planning units in forest enterprises.
\end{abstract}

stocking tree / quality / forest inventory / photogrammetry / automatized grading / image analysis / grading criteria / timber selling contract / Picea abies / Pinus sylvestris

Résumé - Estimation des assortiments potentiels dans une ressource en bois sur pied : une méthode basée sur la photogrammétrie et la classification automatique des arbres échantillonnés. L'article présente une méthode d'évaluation de la qualité d'une ressource en bois sur pied reposant sur la photogrammétrie et incluant une routine de classement automatique des arbres. Cette dernière est fondée sur une interprétation des photographies des tiges à l'aide d'eCognition, un outil d'analyse d'image incluant un processus de segmentation polygonale et un système de classement basé sur la logique floue. La paramétrisation fait référence à des critères qualitatifs-clés identifiés grâce à l'analyse de contrats de vente de bois intervenus dans deux régions-tests de Saxe (Allemagne). Un total de huit épicéas communs (Picea abies Karst.) et de huit pins sylvestres (Pinus sylvestris L.) échantillonnés dans ces deux régions a été utilisé comme matériel d'étude pour développer la méthode de classement avec eCognition. Pour un épicéa et un pin, un exemple d'application est présenté qui montre les différences entre un classement traditionnel et un classement amélioré grâce à la méthode mise au point. Dans le contexte de l'inventaire forestier, la méthode veut introduire une base d'information plus détaillée sur la distribution des assortiments au niveau des unités de la planification de la gestion forestière.

arbre sur pied / qualité / inventaire forestier / photogrammétrie / classement automatique / analyse d'image / critère de classement / contrat de vente / Picea abies / Pinus sylvestris

\section{INTRODUCTION}

Nowadays the change of even-aged, more or less homogenous forests with small assortment variability into multilayered uneven-aged stands and a silvicultural management focussing on single trees represents new challenges for an adapted forest management [21,22]. A modern forest management should consider both the quantity of the growing stock and the quality of the single tree for ensuring a long-term sustainable use of forest resources [7,29]. Furthermore, for raising the profit from timber use, detailed information on the spatial distribution and concrete localisation of qualitative stock clusters is necessary: harvesting measures today are intended at

\footnotetext{
* Corresponding author: fuerst@frsws10.forst.tu-dresden.de
}

concentrating directly on customer-related products for an optimization of the economic benefit $[6,9,15]$.

Consequently, an integration of assortment oriented approaches in the existing (stand-wise) inventory methods is demanded. Value inventory methods like those presented by $[3,18,26]$ or [27] are often based on a non-market oriented visual quality assessment or referred to quality classes based on general grading rules for round wood (e.g. [14]). Besides, information based on visual assessment is influenced by subjective impressions and thus not reproducible. One approach adapted to the problem of subjectivity was developed by Wiegard et al. [29]: the authors proposed the investigation of quality-related criteria, which are transformed in a second step into key-numbers. The grading is realized by a computer-aided classification of the stems according to 
predefined combinations of key-numbers. The quality classes however were pre-defined by the authors.

The discussed approaches support the controlling of the timber value oriented sustainability on the level of large scale planning units, but not an optimization of timber market oriented harvesting measures. Moog and Karlberg [20] identify in this context a lack of flexibility in the economic philosophy of forest enterprises. This leads to a market behaviour, which is often adverse to the actual timber price development: sinking prices will be answered by a higher output of timber and not by a more customer-specified production.

The objective of this paper is to introduce a photogrammetrical value inventory approach oriented on timber marketrelated products. The photogrammetrical investigation was based on preliminary experiences of $[5,11-13,23,28]$. The characterization of grading relevant stem form parameters was complemented by picture analysis for classifying stem surface parameters as basis for a quality assessment of the sample trees $[6,19]$. A modular value inventory system was developed, including the following components: (i) terrestrial photogrammetrical documentation of sample trees, (ii) picture interpretation including stem form and stem surface parameter oriented classification, based on (iii) data base application as link between inventory and forest enterprise, including (iv) a marketoriented evaluation approach for the growing stock.

The article reports primarily the results of the photogrammetrical investigation and the automatized grading. A total of eight Norway spruces (Picea abies, Karst.) and eight Scots pines (Pinus sylvestris, L.) in two test regions in Saxony was selected as sample material for the development of the classification routines in the eCognition software. An application example of the differences between "normal" and "improved" grading will be presented for two sample trees. The data base application and the evaluation approach will be devoted to another paper (see [10]) and thus, will only be introduced in the context of the modular value inventory system.

\section{MATERIAL AND METHODS}

\subsection{Background and sample material}

The presented approach was a subproject in the joint research activity "Future-oriented forestry", which was dedicated in Saxony to the evaluation of conversion effects in pure coniferous stands in the test regions "Middle and Eastern Ore Mountains" and "Lowlands" [8]. The Middle and Eastern Ore Mountains are representing sub-mountainous Norway spruce dominated forest (eco-)systems, whereas the Lowlands are merely dominated by pure Scots pine stands.

The aim of the subproject was among others to analyse, how conversion influences the percentage of merchantable assortments in the growing stock with special consideration of valuable (coniferous) key assortments [6]. Hence, a method for the identification of the assortment potential of stocking trees had to be developed. The material, on which the methodological development and thus, the presented article is based, comprises (1) eight Norway spruces (see Tab. I) originating from the Saxonian forest district "Heinzebank-Pockau" (Ore
Mountains), and (2) eight Scots pines (see Tab. II) originating from the Saxonian forest district "Falkenberg" (Lowlands).

These sample trees were picked out from the sample tree pool of the regional sample plot system, which was installed for the joint research project. The plots in this system represented a chronosequence of characteristic conversion phases. The selection of the here presented sample trees was oriented on a minimum breast height diameter $(\mathrm{DBH}>30 \mathrm{~cm})$ and on their aptitude for photogrammetrical purposes (visible stem, i.e. in this case preferably trees on plots with single-layered old stands were selected). The pre-condition "visibility of the stem" represents a restriction for random sampling of trees and limits the applicability of the photo method in (a) extremely dense stands and (b) in stands with extremely low crown base. In this case, alternatively laser scanning could be applied, but was not tested in the presented study.

The DBH threshold was chosen in order to take into account that an economic relevant assortment differentiation (in Germany) starts normally at a mid-diameter of $>20 \mathrm{~cm}$ ( $=\mathrm{L} \mathrm{2a}$ according to the governmental grading rule HKS, [14]). In the test regions this mid-diameter corresponds for both tree species to a mean DBH of $\geq 30 \mathrm{~cm}$. Furthermore this DBH threshold was conform to the callipering limit of the largest concentric sample circle $(r=12.62 \mathrm{~m})$, which was applied for the regional sample plot design (see e.g. $[2,16])$

Two additional sample trees of the above mentioned regional sample tree pool were chosen for demonstrating an application example of the presented method. They will be introduced in Section 3.3.

\subsection{Field investigations}

The 16 sample trees were documented with a non calibrated "PowerShot A20" digital camera, resolution 600 dpi, each from two different directions and two different distances: for an objective recording of the average quality, the photos were taken from the directions of the smallest and of the largest DBH. For the documentation of stem form features, a distance of $1.5-2 \times$ height $_{\text {(total) }}$ was chosen, where the whole tree can be documented with one shot (= high distance photos). The horizontal distance between camera and tree was measured with the ultrasonic Vertex III ( ${ }^{\circledR}$ Haglöf). As reference system for the later linear rectification of the photos, an object coordinate system with 3 pass points, height $5 \mathrm{~m}$ (see [5]) was used. For the documentation of surface features, a horizontal distance of $10 \mathrm{~m}$ was chosen according to the results of pre-investigations (= low distance photos). Here, two shots were necessary for the documentation of the lower part of the stem (bottom until mid-height) and its upper part (midheight until top). The two shots should have an overlapping zone of 2-3 $\mathrm{m}$ for a later fusion.

For each shot (near and high distance photos), three repetitions were made with variation of matrix or spot related photometry and exposure time.

Additionally, the DBH (calliper), the diameter at a height of $7 \mathrm{~m}$ (D7) (special D7-calliper), the basal height of the first green branch (Vertex III) and the basal height of the first dead branch (Vertex III) were measured as reference for the rectified photos. According to Hendrich [12], re-identifiable marks like the Vertex III transmitter at $1.3 \mathrm{~m}$ height (breast height) and the basal areas of first green/dead branch can serve as "natural pass points" for supporting a rectification of the stem part $>5 \mathrm{~m}$ height.

Finally, the geo-coordinates of the sample plot centre were measured by the hand-held Geo-Explorer ${ }^{\circledR}$ CE-Series ${ }^{\complement}$ Trimble and the 
Table I. Sample Norway spruces Heinzebank-Pockau (Ore Mountains).

\begin{tabular}{|c|c|c|c|c|c|c|c|c|}
\hline Plot number & Plot age* & Tree code & DBH o.b.** & D7 o.b.*** & Height (total) & Height 1st dead branch & Height 1st green whorl & Other \\
\hline $\bar{B} 5 \mathrm{a} 2$ & 99 & $2 \mathrm{Fi} 1$ & 0.39 & 0.28 & 27.0 & 3.7 & 10.2 & \\
\hline B5a1 & 130 & $5 \mathrm{Fi} 2$ & 0.49 & 0.37 & 29.0 & 0.1 & 8.4 & Butt rot \\
\hline Z40a5 & 123 & 6 Fi 3 & 0.44 & 0.32 & 30.1 & 3.3 & 7.7 & \\
\hline B5a1 & 130 & $7 \mathrm{Fi} 4$ & 0.50 & 0,39 & 28.2 & 2.7 & 4.1 & \\
\hline $\mathrm{B} 5 \mathrm{a} 2$ & 99 & 8 Fi 5 & 0.42 & 0.30 & 31.0 & 2.2 & 5.4 & Harv. defect \\
\hline L78a6 & 116 & $11 \mathrm{Fi} 6$ & 0.45 & 0.35 & 30.2 & 3.9 & 8.9 & \\
\hline L78a6 & 116 & $12 \mathrm{Fi} 7$ & 0.47 & 0.34 & 28.7 & 2.4 & 8.1 & \\
\hline Z40a4 & 123 & $16 \mathrm{Fi} 8$ & 0.51 & 0.37 & 28.5 & 0.9 & 3.2 & \\
\hline
\end{tabular}

* According to the most recent forest inventory data.

** DBH o.b. $=$ diameter at breast height over bark.

*** The second diameter recorded for a rectification and correction of the stem shape was the diameter at a height of $7 \mathrm{~m}$, the measurement was also over bark.

Table II. Sample Scots pines Falkenberg (Lowlands).

\begin{tabular}{|c|c|c|c|c|c|c|c|c|}
\hline Plot number & Plot age* & Tree code & DBH o.b.** & D7 o.b. $* * *$ & Height (total) & Height 1st dead branch & Height 1st green whorl & Other \\
\hline $\mathrm{S} 752 \mathrm{a} 3$ & 93 & $1 \mathrm{Kie} 1$ & 0.34 & 0.22 & 28.0 & 10.9 & 16.9 & \\
\hline $\mathrm{S} 752 \mathrm{a} 3$ & 93 & 3 Kie 2 & 0.37 & 0.21 & 28.1 & 11.2 & 16.7 & \\
\hline $\mathrm{J} 584 \mathrm{a} 4$ & 95 & 4 Kie 3 & 0.42 & 0.19 & 29.2 & 15.2 & 17.3 & \\
\hline J584a4 & 95 & 9 Kie 4 & 0.47 & 0.29 & 33.7 & 17.7 & 21.1 & \\
\hline $\mathrm{J} 584 \mathrm{a} 4$ & 95 & 10 Kie 5 & 0.49 & 0.31 & 24.8 & 18.6 & 22.2 & Bumps \\
\hline $\mathrm{S} 752 \mathrm{a} 3$ & 93 & 13 Kie 6 & 0.35 & 0.25 & 24.7 & 11.2 & 18.7 & \\
\hline $\mathrm{J} 584 \mathrm{a} 4$ & 95 & 14 Kie 7 & 0.43 & 0.22 & 27.9 & 15.7 & 17.2 & \\
\hline $\mathrm{S} 752 \mathrm{a} 3$ & 93 & 15 Kie 8 & 0.39 & 0.22 & 25.6 & 11.9 & 18.6 & \\
\hline
\end{tabular}

* According to the most recent forest inventory data, some of the individuals might have been older.

** DBH o.b. $=$ diameter at breast height over bark.

*** The second diameter recorded for a rectification and correction of the stem shape was the diameter at a height of $7 \mathrm{~m}$, the measurement was also over bark.

coordinates of the sample trees were noted in relation to the plot centre (horizontal distance, direction). This offers the option of (1) an area-related transfer of the results and (2) of a later re-investigation of the sample trees for value increment monitoring.

\subsection{Picture processing}

The upper and the lower part of the low distance photos were fusioned within "PhotoStitch 3.1" and the quality (sharpness, contrast) of the result was checked and improved if necessary. This step was followed by cutting in Adobe Photoshop 6.0: the background and all details, which were not grading relevant like the crown, were eliminated. Finally, the pictures were imported in eCognition 2.0., a Dalmatian technology based tool for image analysis, with a polygonoriented segmentation process and a fuzzy logic based classification. The polygon based segmentation takes into consideration that semantic information, which is necessary for a meaningful picture interpretation is not represented in single pixels, but in image objects and their relationships [1]. Pixel based interpretation, which was tested in the course of the project demanded for a clearly longer training and delivered still unsatisfactory results. Fuzzy logic based approaches support dealing with diffuse criteria for the classification of objects and facilitate a realistic definition of object memberships. The fuzzy logic based classification in eCognition uses therefore a broad spectrum of different object features, such as spectral values, shape or texture and enables an automatization by recording and abstraction of the classification steps ("self learning software") [1]. ECognition supports thus the differentiated analysis of stem surface structures and allows in a multistage process, to delineate feature-homogenous zones. Additionally, a rectification based on the "natural pass points" was tested.

The photos documenting the whole stem were processed according to the "Göttinger Messverfahren" [5, 11,23].

\subsection{Data base application}

The parameterisation of the segmentation routine was based on assortment criteria from 20 typical timber selling contracts in the test regions. The selection of these contracts was oriented on the validity period (1998-2002) and on the representativity of the contracts for the customer structure for the forest enterprises in the test regions. At last, contracts from 15 regional (small) and 5 trans-regional (large) timber buyers were chosen. The analysis of key parameters relevant for the definition of customer-related products formed the basis for the development of a quality database "thar- $Q D B$ " on the platform Microsoft Access 2000 and 2002. Two classes of key parameters were identified: (1) parameters concerning the stem dimension (length, DBH, mean diameter, diameter of the small end, tapering) and (2) parameters concerning surface characteristics (number of branches per meter, quality of branches (dead branch, green branch), size of branches, bumps, inhomogeneous surface defects (scars, felling defects)). Parameters referring to the inner quality as well as curvature and spiral grain were not concerned in this approach. 


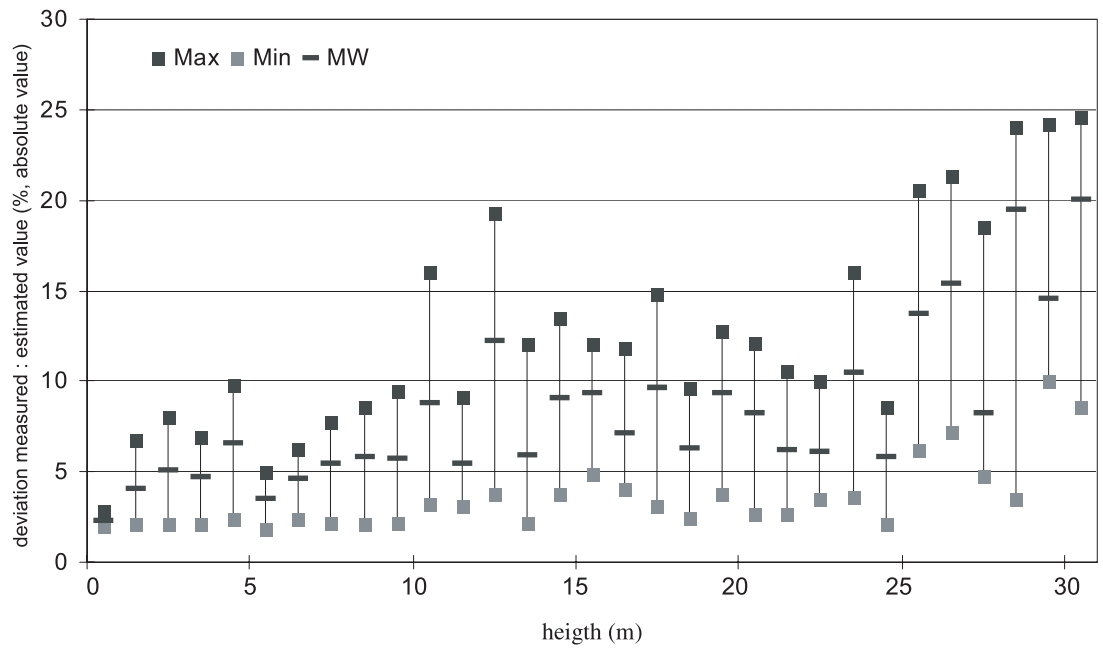

Figure 1. Percentage deviation (absolute value) measured: estimated diameter per meter height for 6 selected sample trees (near distance photos).

\section{RESULTS AND DISCUSSION}

\subsection{Photogrammetrical documentation}

For the photo-based grading, two different kinds of photomaterial were used with different precision levels. The high distance photos showed after the linear rectification differences between measured and estimated values of diameter and height, which were comparable to Dehn et al. [5], where the authors appraised a maximum height error of $6 \mathrm{~cm}$ (standard deviation) and a maximum diameter error of $0.2 \mathrm{~cm}$ (standard deviation), though a non-calibrated camera was used for the presented study. The results were considered as sufficient to be used for a logging according to stem form related assortment criteria (length and medium diameter of the logs).

In contrast, the near distance photos suffered from a higher inaccuracy, which was (1) the result of the selected fusion mode (overlapping zone based) and (2) of problems with the rectification of the fusioned photo material. The insufficient results were among other caused by imprecision of measuring and re-identification of the "natural pass points" (e.g. basal "area" of the first green branch). For a quantification of the difference "measured value: estimated value", six sample trees (3 Norway spruces and 3 Scots pines) were felled. Figure 1 provides information on the deviation (mean, min and max) of the measured mid-diameter per meter length from the estimated value, which was based on fusioned and rectified pictures of the six individuals. The percentage deviation of the measured values from the estimated values (here: absolute value) varied between $2.1 \%$ (min at buttress) and $24.6 \%$ (max at $31 \mathrm{~m}$ height) with an increasing trend over the tree height and a standard deviation of 5.7 (6 sample trees, 31 measurements per tree from 0 to $31 \mathrm{~m}$ height $=>n=186$ ).

For the further development, this photo material was only applied for an identification of surface feature homogenous zones (see Sect. 3.2).

\subsection{Grading}

The analysis of the timber selling contracts for the test regions revealed that $\log$ mid-diameter, length and tapering as stem dimension related attributes and branchiness (including scars, bumps, surface irregularities) as stem surface feature related attributes were the key assortment criteria. The assortment specific thresholds for stem dimensions and stem surface criteria were customer dependent. The thresholds for stem surface criteria like branchiness were characterized by their total number per $m$ length and by the diameter and current state of the respective criterion, e.g. living (green) or dead branch. The stem dimension related criteria were categorized through distinct numeric thresholds. For the administration and supply of the assortment criteria for the grading routine, a database application thar- $Q D B$ (Tharandt Quality Data Base) was developed as subject-matter of a diploma thesis [19].

The grading process was separated into two sections, (1) a stem surface feature oriented classification (sorting), which was based on the near distance photos and (2) a stem dimension feature referred classification (sizing), which was based on the high distance tree photos. The section (1) was devoted to the identification of feature homogenous zones according to assortment specific criteria combinations. The succeeding section (2) was designed as a kind of virtual logging including an optimization routine of the assortment length. The results of the complete grading process were exported to thar- $Q D B$. A monetary evaluation routine of the different grading alternatives supports the identification of the best assortment combination (length/diameter + quality) out of an economic point of view. The evaluation in thar- $Q D B$ includes also a link of customer oriented assortments with quality and diameter classes of the governmental grading rule (HKS). This delivers market situation independent data for a comparative evaluation of the growing stock value in time series.

The sorting in section (1) is a multi-stage process within eCognition. The first action is a multi-resolution segmentation, 


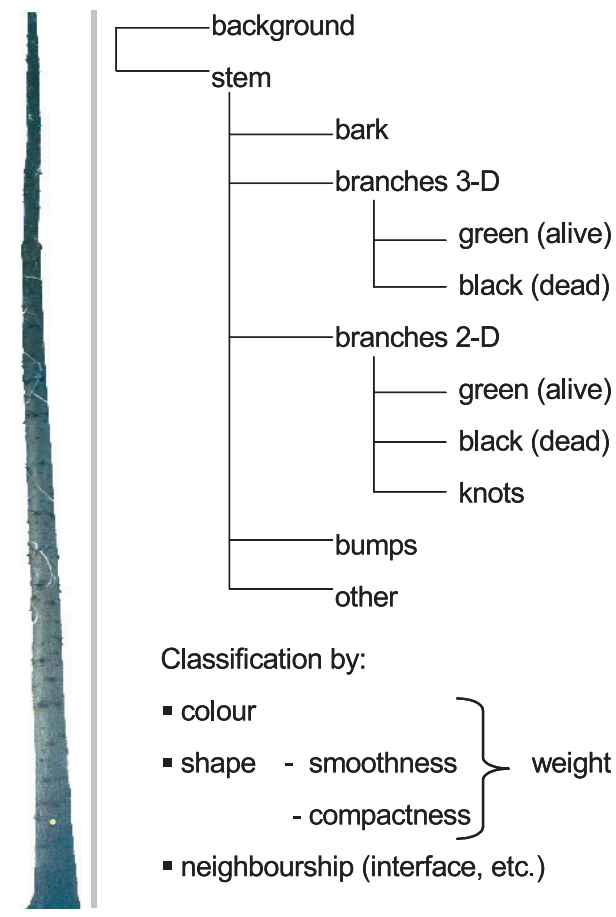

Figure 2. Class structure and classification criteria for 1st program pass in eCognition.

i.e. a polygon-based segmentation according to colournuances, where the parameterisation results from the stem surface-related assortment criteria. This is followed by a classification of areas with homogenous surface characteristics. Afterwards, the definition of structure groups and a classification based segmentation helps to assign the numerous polygons to classes. Additional child classes can be defined, e.g. according to tree species-specific requirements for branch size classes.

Figure 2 shows a generalizeable class hierarchy for the two program passes within eCognition (see Fig. 3).

The hierarchical classification approach in eCognition demands to define first the overall classes "background" (i.e. "not sample tree") and "stem". In the next step, the "stem" child classes "bark", "3-D-branches" (escape from photo plane), "2D-branches" (stay in photo plane) as well as "bumps" and "other" (e.g. harvesting defects, bark peeling wounds, etc.) are defined. The child classes "3-D" and "2-D"- branches can be divided into further child classes. The variation of the weight, which is given to shape and colour values and the definition of neighbourship relations of the respectively classified polygons enable to identify grading relevant surface features. Branches for instance show in contradiction to bumps normally an easily definable borderline. The borderline of 2-D-branches shows generally deeper grey values and appears clearer as the borderline of 3-D-branches, where the shadow of the branch smears in dependence from the exposure at least one borderline side.

After the 1st program pass, a logic control of the classification results by the operator is necessary for correcting possible classification mistakes. Especially barky tree species like Scots pine impede the identification of small but price relevant scars and bumps due to inhomogeneous colour and shape of the bark. This logic control however implies the eventuality of a subjective bias of classification result, which at the actual development state can not be eliminated in favour of realistic results. Next, the results of the first program passage must be re-imported as thematic layer (weight 1.0) into eCognition (2nd program pass). The different segmentation and classification steps of the 1 st program pass must be repeated in order to delineate feature-homogenous zones.

Taking one of the Scots pines as example, Figure 3 provides an overview on the total steps until the delineation of feature homogeneous zones (= sorting: section (1) of the grading process). After a "calibration phase" (self-learning program), the two program passes shown in Figure 3 delivered sufficient results for the presented sample trees. The calibration phase demanded in the case of Scots pine 10 repetitions of the two programme passes for the first sample tree, in the case of Norway spruce, 6 repetitions were enough in order to achieve verisimilar and reproducible results.

Section (1) (sorting) can be repeated several times in order to calculate different assortment combinations for later identification of the "best" assortment combination out of economic point of view. As rule of thumb, not more than 5 different combinations should be tested. Each combination will be exported as result to thar- $Q D B$ for subsequent sizing (Sect. 2). Sorting "top down" i.e. starting with the criteria of the most valuable assortments is recommended in order to reduce the number of assortment combination alternatives and can be managed by the input options of thar- $Q D B$ (pre-selected sorting).

Section (2) (sizing) provides information on possible logging according to stem form characteristics and different assortment combinations. The merged results of sorting and sizing are hosted in thar- $Q D B$ for subsequent monetary evaluation and optimization ("best alternative") and can be actualized in case of changing assortment criteria by a reclassification of the sample trees. Thar- $Q D B$ offers the option to keep at the moment 5 grading alternatives (sorting + sizing, default for the case of other than economic optimization criteria), for the following calculations (see Sect. 3.3) only the "best alternative" out of economic point of view was considered.

Figure 4 resumes schematically the total process of sorting, sizing and monetary evaluation and the interfaces to the database thar- $Q D B$ and the user. The numbers 1-6 indicate the cycle until the output for the user.

\subsection{Practical application}

In the following, a comparison of the results for "normal" grading and an "improved" grading will be presented for two sample trees - one Norway spruce (DBH $48 \mathrm{~cm}$, height $35 \mathrm{~m}$, stem volume until minimum top end diameter $2.51 \mathrm{~m}^{3}$ ) and one Scots pine (DBH $53 \mathrm{~cm}$, height $32 \mathrm{~m}$, stem volume until minimum top end diameter $2.63 \mathrm{~m}^{3}$, see also Tab. III). These two trees origin from the regional sample tree pool, and were chosen because they allowed demonstrating exemplary high monetary differences between the two grading approaches.

"Normal" grading as reference is based on the practical customs in the test regions Ore Mountains and Lowlands. Usually, 
a) $1^{\text {st }}$ program pass

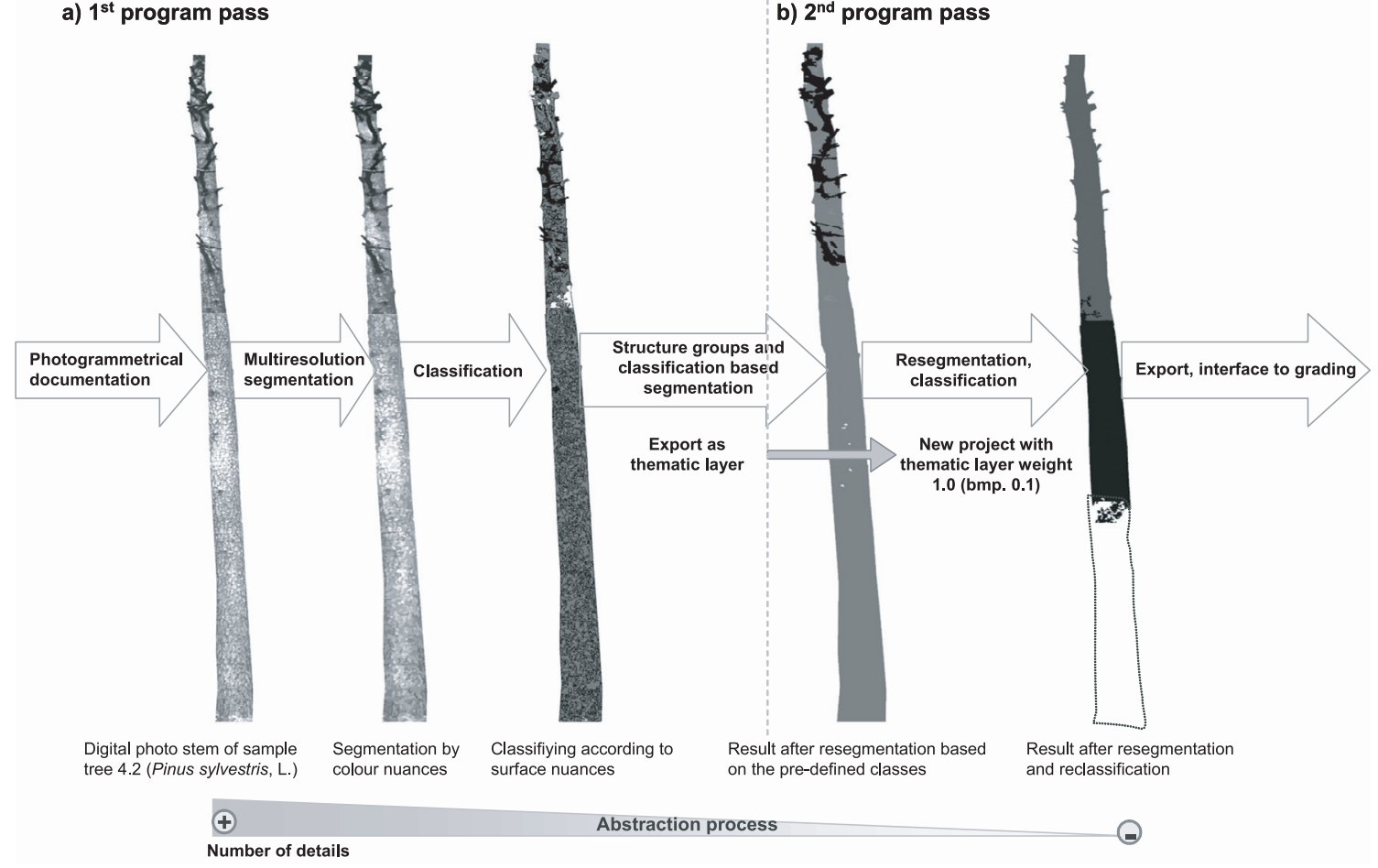

Figure 3. Grading in eCognition - a multistage abstraction process.

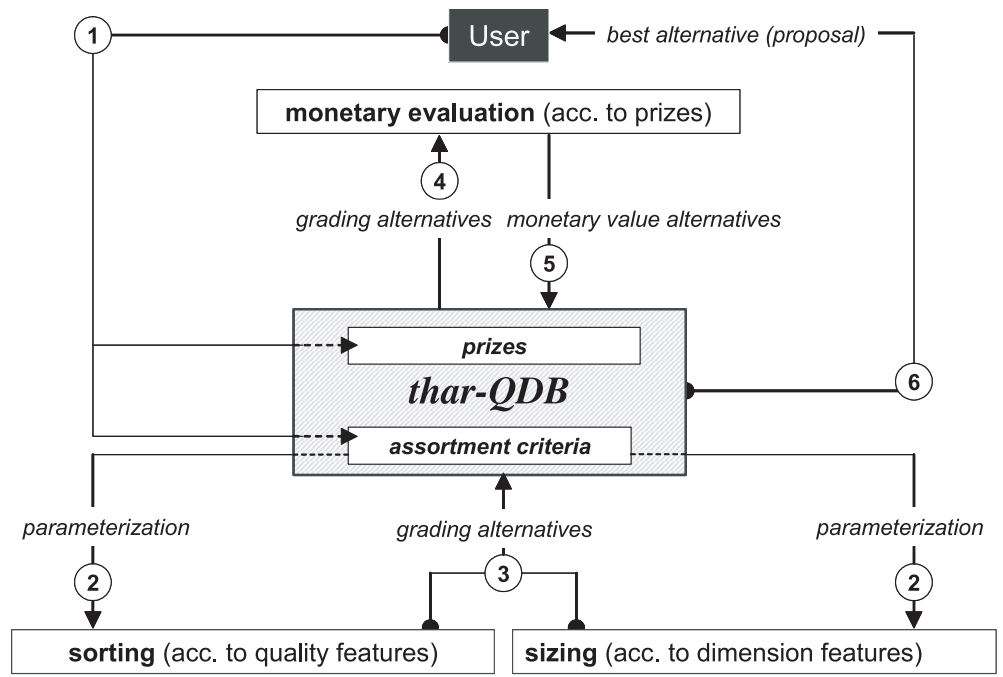

Figure 4. Overview on the grading process and interfaces to thar- $Q D B$ and user.

one or two $8 \mathrm{~m}$ logs (timber/PZ) and in the following several 4 or $2 \mathrm{~m} \mathrm{logs}$ (industrial wood) are distinguished until a top end diameter of 10 (under bark, u.b.) - 11 (over bark, o.b.) cm for Norway spruce and 12 (u.b.) - 13 (o.b.) cm for Scots pine.

"Improved" grading includes the effects of quality-oriented optimization but also of an optimized log length, which comprises an increasing percentage volume of timber, a reduced percentage volume of industrial and fuel wood and a better exploitation of the total stem until the minimum possible top end diameter. The comparison refers to the price level 1998 2000.

Figures $5 \mathrm{a}-5 \mathrm{~d}$ show the volume of the sample trees over the height, the differences in logging of "normal" and "improved" grading and the average prices per logging unit.

Considering the derivation of the presented results, Table III resumes the dendrometrical data of both sample trees and gives an overview on volume, price/volume unit and total price of the logs for the two grading alternatives. 
Table III. Dendrometrical data of the sample trees, log volumes and prices for the two grading alternatives "normal grading" and "improved grading".

\begin{tabular}{|c|c|c|c|c|c|c|}
\hline Sample tree & Norway spruce & & & Scots pine & & \\
\hline$\overline{\mathrm{DBH}(\mathrm{cm})}$ & 48 & & & 53 & & \\
\hline Height (m) & 35 & & & 32 & & \\
\hline Volume $\left(\mathrm{m}^{3}\right.$ & 2.51 & & & 2.63 & & \\
\hline \multicolumn{7}{|l|}{ Normal grading } \\
\hline Price $\left(€ / \mathrm{m}^{3}\right)$ & 41.34 & & & 44.27 & & \\
\hline Total price $(€)$ & 103.76 & & & 116.43 & & \\
\hline Number of logs & 6 & & & 5 & & \\
\hline Logs & Volume $\left(\mathrm{m}^{3}\right)$ & Price $€ /\left(\mathrm{m}^{3}\right)$ & Total price $(€)$ & Volume $\left(\mathrm{m}^{3}\right)$ & Price $€ /\left(\mathrm{m}^{3}\right)$ & Total price $(€)$ \\
\hline Timber (1 log) & 1.26 & 50.44 & 63.56 & 1.47 & 55.08 & 80.97 \\
\hline Timber $(1 \log )$ & 0.80 & 50.00 & 40.00 & 0.81 & 44.25 & 35.84 \\
\hline Ind. timber $(4 \operatorname{logs})^{*}$ & 0.43 & 0.47 & 0.20 & 0.33 & $* *-1.15$ & -0.38 \\
\hline Rest & 0.02 & 0.00 & 0.00 & 0.02 & 0.00 & 0.00 \\
\hline \multicolumn{7}{|l|}{ Improved grading } \\
\hline Price $\left(€ / \mathrm{m}^{3}\right)$ & 84.08 & & & 81.65 & & \\
\hline Total price $(€)$ & 211.04 & & & 214.74 & & \\
\hline Number of logs & 6 & & & 6 & & \\
\hline Logs & Volume $\left(\mathrm{m}^{3}\right)$ & Price $€ /\left(\mathrm{m}^{3}\right)$ & Total price $(€)$ & Volume $\left(\mathrm{m}^{3}\right)$ & Price $€ /\left(\mathrm{m}^{3}\right)$ & Total price $(€)$ \\
\hline Veneer $(1 \log )$ & 0.84 & 100.27 & 84.23 & 1.00 & 116.32 & 116.32 \\
\hline Timber $(2 \log s)^{*}$ & 1.14 & 86.63 & 98.76 & 0.73 & 72.25 & 52.74 \\
\hline Timber $(1 \log )$ & 0.29 & 72.34 & 20.98 & 0.48 & 71.95 & 34.54 \\
\hline Ind. timber $(2 \operatorname{logs})^{*}$ & 0.19 & 37.26 & 7.08 & 0.40 & 27.85 & 11.14 \\
\hline Rest & 0.05 & 0.00 & 0.00 & 0.02 & 0.00 & 0.00 \\
\hline
\end{tabular}

* In the case of similar prices / $\mathrm{m} 3$ or for the low price segments (industrial and pallet wood), the results were bundled.

** The negative price was a calculatory price given by the forest administration.

Table IV. Duration of single working steps and calculation of average costs per sample tree.

\begin{tabular}{|c|c|c|c|}
\hline Working steps & Duration (min) & Rep. working step & Total duration (min) \\
\hline A. plot reaching & $10-30(15)$ & 1 & 15 \\
\hline B. DBH-measuring ( $\min / \max \mathrm{DBH}+$ documentation direction) & 5 & 1 & 5 \\
\hline \multicolumn{4}{|l|}{ C. Investigation } \\
\hline C.1 Positioning sensor Vertex III & 1 & 2 & 2 \\
\hline C. 2 Measuring / documenting horiz. distance ( $10 \mathrm{~m} / 1.5-2 \times$ tot. height $)$ & $2-5(3)$ & 4 & 12 \\
\hline C. 3 Measuring / documenting basis first dead branch / first green whorl & 1 & 4 & 4 \\
\hline \multicolumn{4}{|l|}{ D. Photographic documentation } \\
\hline D.1 installation / deinstallation tripod + camera & $2-3(2,5)$ & 2 & 5 \\
\hline D. 2 moving tripod & 1 & 3 & 3 \\
\hline D. 3 adjustment camera (matrix / spot, exposure) & $0,5-1(0,75)$ & 18 & 14 \\
\hline D. 4 shooting (2 directions / 2 distances) & 0 & 18 & 2 \\
\hline Average duration field investigations (h) & & & $62(1 \mathrm{~h})$ \\
\hline \multicolumn{4}{|l|}{ E. Data processing } \\
\hline E.1 Data transfer camera - PC & 2 & 1 & 2 \\
\hline E.2 Selection shots - visual comparoison (sharpness / contrast) & 5 & 1 & 5 \\
\hline E.3 Fusioning, improvement quality, cutting & 15 & 2 & 30 \\
\hline \multicolumn{4}{|l|}{ F. Grading according to stem surface features } \\
\hline F.1 Data import eCognition & 1 & 2 & 2 \\
\hline F.2 Segmentation / classification 1st loop & $20-30(25)$ & 2 & 50 \\
\hline F.3 Re-import and re-segmentation / classification 2nd loop & $10-15(12,5)$ & 2 & 25 \\
\hline F.4 Export (coordinates) & 1 & 2 & 2 \\
\hline G. Grading according to stem dimension features & 30 & 2 & 60 \\
\hline Duration classification process (h) & & & $176(3 \mathrm{~h})$ \\
\hline Total duration $(\mathbf{h})$ & & & $238(4 \mathrm{~h})$ \\
\hline \multicolumn{4}{|l|}{ Costs } \\
\hline Field investigations: $30,-€ / \mathrm{h}$ (level in 2001) & & & $30,-€$ \\
\hline Data analysis : 40,- $€ / \mathrm{h}$ (level in 2001) & & & $120,-€$ \\
\hline Costs per sample tree & & & $150,-€$ \\
\hline
\end{tabular}




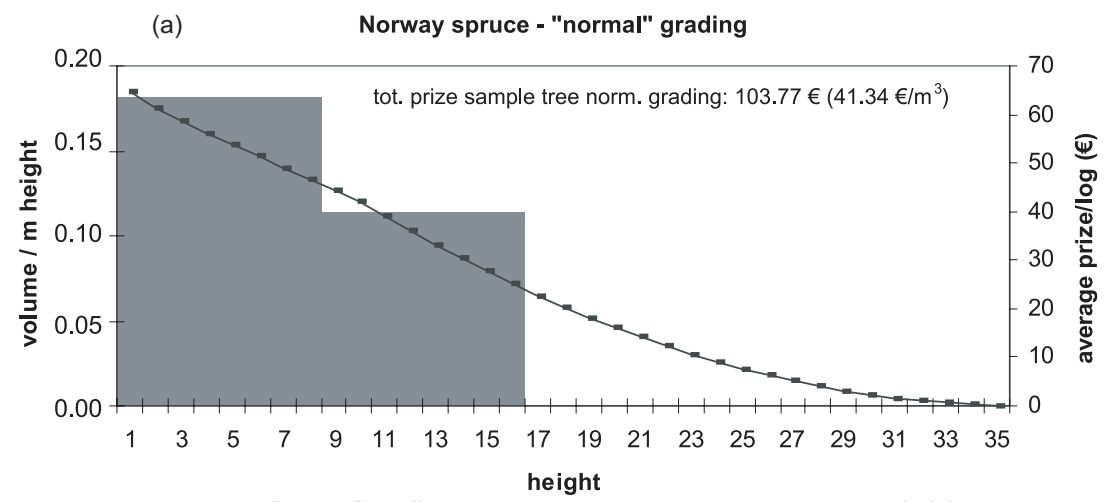

logs "normal" grading

- volume over height

(b)

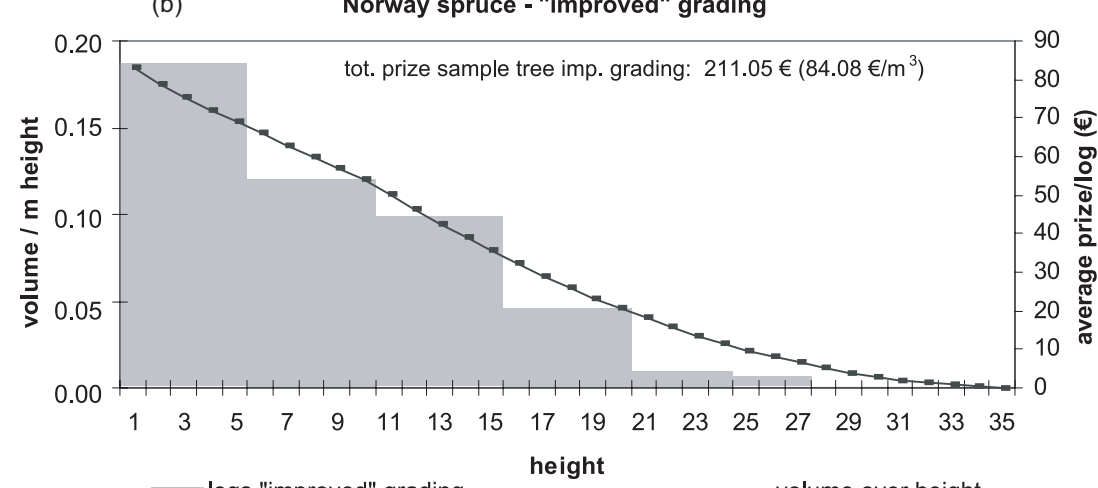

logs "improved" grading

(c)

Scots pine - "normal" grading

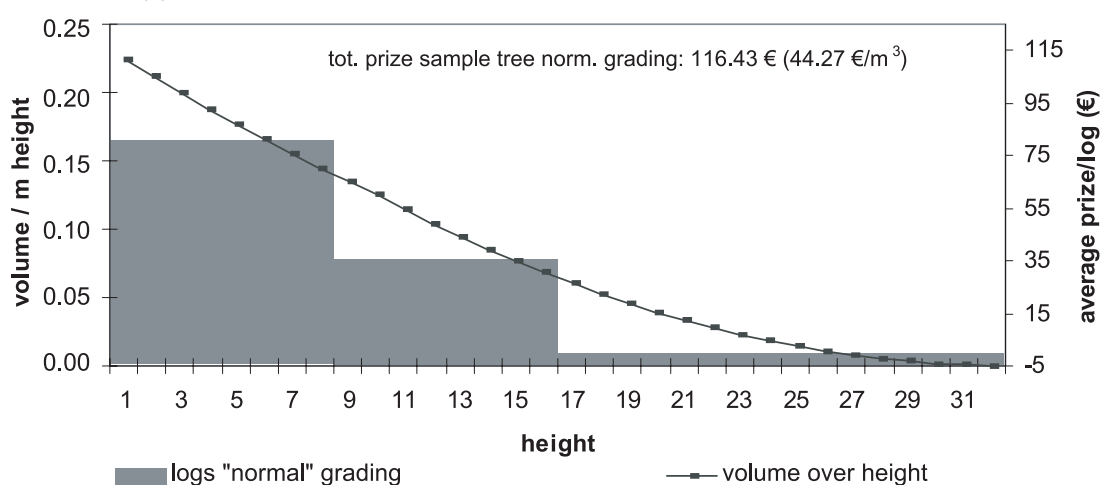

(d) Scots pine - "improved" grading

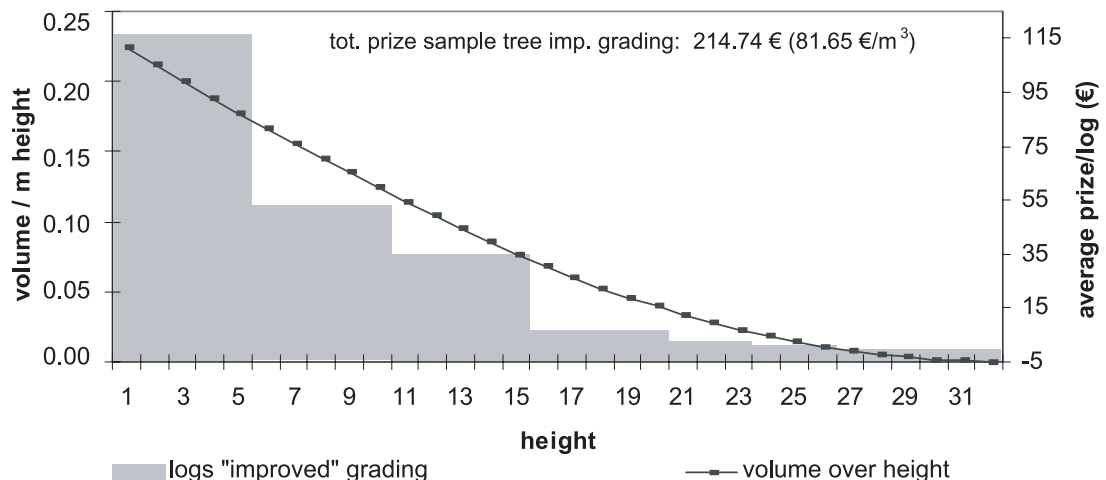

Figure 5. (a and b) Comparison "normal" / "improved" grading for one Norway spruce. (c and d) Comparison "normal" / "improved" grading for one Scots pine. 
The demonstration highlightens the potential profitability of the "improved" approach and reveals a considerable monetary difference of the results compared to normal grading. For the Norway spruce, "normal" grading met an average price per $\mathrm{m}^{3}$ of $41.34 €$, whereas an "improved" grading revealed the possibility to achieve $84.04 € / \mathrm{m}^{3}$. This result ensued primarily from the reduced log length of the "improved" approach, which allowed to use optimally the mid-diameter related price differences of the logs (according to the analyzed contracts) and to use a higher percentage of the stem length. For the Scots pine, the normal grading resulted in an average price per $\mathrm{m}^{3}$ of $44.27 €$, whereas the "improved" approach revealed a potential of $81.65 € / \mathrm{m}^{3}$. In this case - in addition to the optimized log length, the observed difference can be explained by a considerably higher profit resulting from quality oriented grading in the valuable stem parts (up to $5 \mathrm{~m}$ ) and by the reduction of the percentage of non-profitable assortments in the stem parts over a height of $16 \mathrm{~m}$. Both examples show that the calculated profit for an "improved" grading can surpass those from "normal" grading up to $100 \%$.

Costs for different harvesting and processing alternatives were not yet included in this calculation. Regarding higher operating expenditure for "improved" grading, an integration of these costs can reduce the observed profitability.

Taking as example value inventory in a test forest enterprise of 3500 ha, a surplus value of the growing stock amounting up to $1500 € / \mathrm{ha}(=+17.42 \%$, including harvesting and processing costs) was assessed, when comparing the results of monetary evaluation based (a) on "normal" grading and (b) on "improved" grading $[6,10]$. This example indicates the possible financial magnitude of the growing stock value, which is underestimated by a non-quality-oriented (normal) inventory.

However, regarding cost efficiency of forest inventory, the proposed method excludes at the actual state large sample sizes due to the required time for photos and picture interpretation: actually the costs/sample tree amount to $150 €$ (Tab. IV). This means that a sample size of 10 sample trees/ha would nullify e.g. the possible surplus value calculated for the test enterprise.

For practical application sample sizes between 15-20 trees per planning unit (stand, stratum $>1$ ha) and tree species are proposed, according to the thresholds published by [16] and [25]. This means that maximally one sample tree per plot should be selected. Otherwise, the clustering effect in tree quality on the plots would provoke an unacceptable bias for the up-scaled results. The transfer of the results (here: assortment distribution) from single sample tree to sample plot and finally to planning unit can be realized by recalculation of the repetition factor (= area represented by one sample plot) of the georeferenced sample plots of the forest inventory sample plot grid in the respective management unit. The "new" sample plot size results from the horizontal distance between the plot centre and the centre of the nearest eligible value inventory sample tree $\left(r_{\text {new }}=\operatorname{dist}(\right.$ plot centre, sample tree 1$\left.)+r_{\text {sample tree }}\right)$. "Eligible" means in this context selection according to DBH threshold and tree species; for practical photographical documentation, also a sample tree with higher distance to the plot centre might be chosen for reasons of stem visibility.

\section{CONCLUSIONS AND PERSPECTIVES}

The photo-documentation of sample trees can be used for the calculation of stem dimensions and for the interpretation of stem surface features. The results form the basis for a nondestructive and objective assessment of the assortment distribution of planning unit (stand/stratum) representative sample trees [10]. Lejeune et al. [17] showed that visual estimation of tree dimensions can deliver results, which are qualitatively comparable to classical manual measurements. However, considering tree quality and grading of standing trees, (1) the necessary objectivity can not be realized and (2) the visibility of quality relevant stem surface properties decreases with increasing tree height [29]. The presented experimental approach aims at introducing a quality-oriented grading of stocking sample trees, which is based on an automatized interpretation of photos in order to achieve the maximal objectivity and reproducibility of the grading results. As restriction, linking with wood traits and internal defects was not yet realized and can be identified as further development target (e.g. $[4,24,29])$. Furthermore, stem form related assortment criteria like stem curvature and ovality of the cross section were excluded from the presented approach because the analyzed timber selling contracts did not focus on these stem form attributes. However, this might be only a regional point of view. Thus, these criteria will have to be included in the further development of the approach.

The average costs of $150 € /$ sample tree for grading require actually a limited number of sample trees/planning unit for an economic reasonable application of the approach. Consequently, practical application might be limited on demonstration purposes. The approach supports visualization and exemplary monetary evaluation of grading alternatives for sample trees and thus can be employed for training to support an improved understanding of the value potential of the growing stock. However, a further automatization of the cost extensive grading process forms an indispensable step for the acceptance of this method in the forest practice.

Acknowledgements: The authors wish to acknowledge especially the colleagues of the Saxonian Forest Districts Falkenberg (FD Dr. Zimmermann) Heinzebank-Pockau (FD Haase) and Laußnitz (FD Glock) for their support during the investigations. Special thanks to Prof. Dr. Heinz Röhle, Dresden University of Technology, and particularly to Dr. Thomas Seifert, Munich University of Technology, and Matthias Menzel (State Forest Administration Rhineland-Palatinate) for the helpful discussions on methodological approaches and numerous ideas and tips. Thanks also to Prof. Dr. Joachim Saborowski and Dr. Dieter Gaffrey, University of Göttingen, for technical advice. The research project was supported by the German Ministry for Education and Research (BMBF).

\section{REFERENCES}

[1] Baatz M., Heynen M., Hofmann P., Lingenfelder I., Mimler M., Schäper A., Weber M., Willhauck G., eCognition, Object-oriented Image Analysis, User Guide, DEFINIENS Company, 351 p.

[2] Bitter A.W., Die typenorientierte Kontrollstichprobe als Verfahrenskonzept für die Forsteinrichtung, Beiträge zur Forstökonomik, Schriftenreihe des Instituts für Sozioökonomik der Forst- und Holzwirtschaft, Eigenverlag des Instituts Wien, 10 p. 
[3] Brabänder H.D., Gesetzmäßigkeiten im Volumenaufbau und Wertaufbau des Schaftes als Grundlage zur Qualitätskontrolle von Laubholzbeständen, Dissertation University of Freiburg, in: Kramer H., AKCA A., Leitfaden zur Waldmesslehre, JD Sauerländer's Verlag, Frankfurt am Main, 1995, 266 p.

[4] Constant T., Mothe F., Badia M.A., Saint-André L., How to relate the standing tree shape to internal wood characteristics: Proposal of an experimental method applied to poplar trees, Ann. For. Sci. 60 (2003), p. 371-378

[5] Dehn R., Taube D., Sloboda B., Schaftvermessung an stehenden Bäumen mit einem eindimensionalen Passpunktsystem, AFZ 15 p. $350-353$.

[6] Fürst C., Value inventory and value control for a yield oriented survey or ecological conversion, in: Fürst C., Bitter A.W., Eisenhauer D.R., Makeschin F., Röhle H., Roloff A., Wagner S. (Eds.), Sustainable Methods and ecological processes of a conversion of pure Norway spruce and Scots pine stands into ecologically adapted mixed stands, Contributions to Forest Sciences, Ulmer Verlag (2004) pp. 220-234.

[7] Fürst C., Klins U., Knoke T., Suda M., Bitter A.W., Multifunctional demands to forestry - Societal background, evaluation approaches and adapted inventory methods for the key functions protection, production, diversity and recreation, in: Andersson F., Birot Y., Paivinen R. (Eds.), Towards the Sustainable Use of Europe's Forests - Forest Ecosystem and Landscape Research: Scientific Challenges and Opportunities, EFI Proceedings, 49, 2004, pp. 113-124.

[8] Fürst C., Bitter A.W., Eisenhauer D.R., Makeschin F., Röhle R., Roloff A., Wagner S. (Eds.) Sustainable methods and ecological processes of a conversion of pure Norway spruce and Scots pine stands into ecologically adapted mixed stands, Contributions to Forest Sciences, Ulmer Verlag, 2004, 250 p.

[9] Fürst C., Seifert T., Integration der Holzqualität in die Forst-HolzKette/Integration of wood-quality into the forest-wood-chain, Forst und Holz 59 (2004) 190-194.

[10] Fürst C., Nepveu G., Menzel M., Évaluation de l'assortiment d'une ressource en bois sur pied ciblée sur la satisfaction des besoins du marché du bois - Présentation d'une méthode pratique développée en Allemagne, Rev. For. Fr. (in print).

[11] Gaffrey D., Sortenorientiertes BestandeswachstumsSimulationsmodell auf der Basis intraspezifischen konkurrenzbedingten Einzelbaumwachstums - insbesondere hinsichtlich des Durchmessers am Beispiel der Douglasie, Berichte des Forschungszentrums Waldökosysteme, Reihe A, Bd. 133, 1996, $413 \mathrm{p}$.

[12] Hendrich C., Eine photogrammetrische Methode zur Vermessung von Baumkronen, Diplomarbeit Institut II Experimental- und Angewandte Physik, TU München, 1996, 350 p.

[13] Hengl T., Krizan J., Kusan V., TREE3D - Program f. measurement of indiv. trees using close range photogrammetry, Mehanisacija Sumarstva 22 (1997) 141-147

[14] HKS, EWG, 1968, BRD, RL Rat d. EWG z. Angleichung d. Rechtsvorschriften der Mitgliedstaaten für die Sortierung von Rohholz, BRD, 1969: Gesetz über gesetzl. Handelsklassen für Rohholz, BGBL 1, p. 149.
[15] Kätsch C., Starkholzinventur mit Hilfe von Luftbildern, Forst Holz 53 (1998) 227-231.

[16] Kramer H., Akca A., Leitfaden zur Waldmesslehre J.D Sauerländer's Verlag, Frankfurt am Main, 1995, 266 p.

[17] Lejeune P., Hébert J., Bousson E., Verrue V., Rondeux J., L'inventaire par évaluation visuelle de grosseurs d'arbres, une alternative pertinente aux inventaires forestiers complets, Ann. For. Sci. 62 (2005) 343-349.

[18] Mahler G., Willmann U., Wurster M., Ansprache der Güte am stehenden Stamm, Holzzentralblatt 102 (2001) 1245-1246.

[19] Menzel M., Entwicklung einer Datenbankanwendung zur Erfassung von Holzabnehmeranforderungen an den Holzproduzenten, Diplomarbeit TU Dresden, 2004, 101p.

[20] Moog M., Karberg B., Ökonomische Gesichtspunkte zur Zielstärke von Kiefern und Buchen, Allgemeine Forstzeitschrift (47) 1992, 85-90.

[21] Nagel J., Albert M., Schmidt M., Das waldbauliche Prognose- und Entscheidungsmodell BWINPro 6.1. Forst u. Holz (57) 2002 486493.

[22] Pretzsch H., Biber P., Dursky J., The single tree-based stand simulator SILVA: construction, application and evaluation, For. Ecol. Manage. (162) 2002 3-21.

[23] Saborowski J., Entwicklung biometrischer Modelle zur Sortimentenprognose, Dissertation an der Georg-AugustUniversität Göttingen, Fakultät Forstwissenschaft, 1982, 46 p.

[24] Seifert T., Integration von Holzqualität und Holzsortierung in behandlungssensitive Waldwachstumsmodelle, Dissertation an der Technischen Universität München, Fakultät Wissenschaftszentrum Weihenstephan für Ernährung, Landnutzung und Umwelt, 2004, $330 \mathrm{p}$.

[25] Smelko S., Untersuchungen d. Variabilitätskoeffizienten der Holzmasse von Beständen auf Kreisprobeflächen m. Hinsicht auf die Präzisierung seiner Abschätzung v. d. Messung, Sbornik VSLS, Zvolen, in: Kramer H., Akca A., Leitfaden zur Waldmesslehre, JD Sauerländer, 1995, 266 p.

[26] Speidel G., Die Wertklasse als Gütemaßstab in der Forsteinrichtung, Forstarchiv, 26 (1955) 217-224

[27] Stepien E., Gadola C., Lenz O., Schär E., Schmid-Haas P., Die Taxierung der Holzqualität am stehenden Baum, Ber. d. Eidgen. Forstl. Forschungsanst. Wald, Schnee u. Landschaft 344, 1998, $68 \mathrm{p}$.

[28] Thomas R., Analyse des formes de troncs par photogrammétrie pour caractériser la qualité des bois., Application au pin sylvestre de Lozère, Ph.D. thesis in Wood Science, Engref, Montpellier, 2000, $193 \mathrm{p}$.

[29] Wiegard C., Netzker D.V., Gadow K., Die Erdstück-Methode der Wertinventur, Forstarchiv 68 (1997) 144-148. 